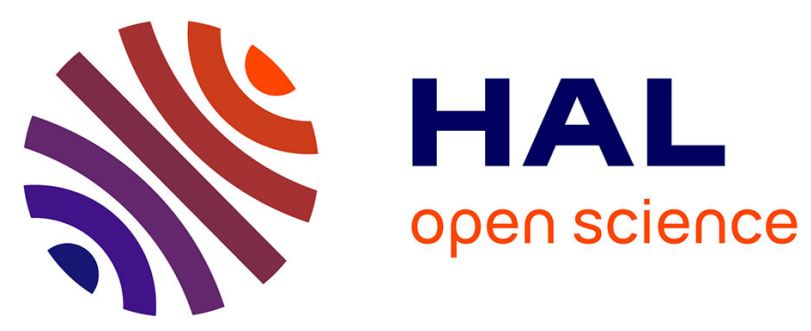

\title{
Measuring and modelling soil erosion and sediment yields in a large cultivated catchment under no-till of Southern Brazil
}

\author{
Elizeu Jonas Didoné, Jean Paolo Gomes Minella, O. Evrard
}

\section{To cite this version:}

Elizeu Jonas Didoné, Jean Paolo Gomes Minella, O. Evrard. Measuring and modelling soil erosion and sediment yields in a large cultivated catchment under no-till of Southern Brazil. Soil and Tillage Research, 2017, 174, pp.24 - 33. 10.1016/j.still.2017.05.011 . hal-01584132

\section{HAL Id: hal-01584132 \\ https://hal.science/hal-01584132}

Submitted on 26 May 2020

HAL is a multi-disciplinary open access archive for the deposit and dissemination of scientific research documents, whether they are published or not. The documents may come from teaching and research institutions in France or abroad, or from public or private research centers.
L'archive ouverte pluridisciplinaire HAL, est destinée au dépôt et à la diffusion de documents scientifiques de niveau recherche, publiés ou non, émanant des établissements d'enseignement et de recherche français ou étrangers, des laboratoires publics ou privés. 


\section{Measuring and modelling soil erosion and sediment yields in a large cultivated catchment under no-till of Southern Brazil}

\section{Elizeu Jonas Didoné ${ }^{1}(*) \cdot J e a n$ Paolo Gomes Minella ${ }^{1} \cdot$ Olivier Evrard $^{2}$}

${ }^{1}$ Soil Science Department, Federal University of Santa Maria, Av. Roraima 1000, 97105900, Santa Maria, Brazil

${ }^{2}$ Laboratoire des Sciences du Climat et de l'Environnement (LSCE/IPSL), Unité Mixte de Recherche 8212 (CEA, CNRS, UVSQ), Université Paris-Saclay, F-91198 Gif-sur-Yvette Cedex, France.

\section{(*) Corresponding author:}

Elizeu Jonas Didoné

Avenida Roraima ${ }^{\circ}$ 1000, Prédio 42, sala 3311ª, Santa Maria-RS-Brazil, CEP: 97105-900 Phone $+55(55) 999718525$.

E-mail: didoneagroufsm@gmail.com

\section{Abstract}

Erosion processes can be exacerbated when inappropriate soil conservation

2 practices are implemented. In Brazil, very few measurements are available to quantify the

3 impact of conservation practices on erosion processes in agricultural catchments. The

4 objective of this study is to quantify the impact of different conservation measures on soil

5 erosion and sediment dynamics in an agricultural catchment under no-till of southern

6 Brazil, and to simulate conservation scenarios using a model calibrated with sediment data

7 measured at the catchment outlet. Monitoring was carried out in a large agricultural

8 catchment $\left(800 \mathrm{~km}^{2}\right)$ of southern Brazil affected by extensive soil erosion and runoff

9 despite the widespread use of no-till. Rainfall, river water discharges and suspended sediment concentrations were monitored during a five-year period (2011-2015). The WaTEM/SEDEM model was then calibrated. Then, four scenarios including a Business- 
As-Usual (BAU) scenario and the implementation of alternative conservation strategies were simulated, and their impact on erosion, sediment deposition and sediment yield was quantified. All four scenarios were simulated twice, using either rainfall measured during a dry year or during a humid year. All the scenarios including alternative conservation measures drastically reduced erosion and sediment yields, with reductions reaching up to $400 \%$ when compared to the BAU scenario. The implementation of mechanical conservation measures such as crop levelling and terracing had the highest impact on soil erosion, and the most effective scenario included the implementation of crop rotation, crop levelling, terracing and the creation of forest protected areas. Model simulations indicated that no-till alone has a low impact on erosion processes and that additional measures increasing the vegetation cover/density of the soil are necessary to significantly reduce sediment transfers in these agricultural areas. The simulations also demonstrate that during wet years, erosion processes increase on average by $33.9 \%$ for all scenarios. This study demonstrates that soil losses due to erosion processes remain significant and unsustainable in agricultural catchments of southern Brazil. Soil erosion is exacerbated by the lack of information provided to the farmers and the use of isolated conservation measures without coordination at the catchment scale. Farmers' and local communities' awareness should be raised to reduce soil degradation and sediment transfer to river systems.

Key words: Soil Conservation; No-till; Connectivity; Sediment yield; WaTEM/SEDEM model; Terraces. degradation, which threatens the global sustainability of the food production systems (Lal et al., 2012). In tropical and subtropical regions, soil erosion has often been accelerated by 
soil conservation measures, such as crop rotation, runoff control and contour farming.

Several studies showed that soil degradation generates the loss of basic soil properties relevant to the farming system and/or an increase of the production costs (Derpsch et al., 2014; Lal, 2007; Reicosky, 2015).

In southern Brazil, farmers have often reduced conservation agriculture to the use of no-till alone (Reicosky, 2015). However, minimum tillage is not sufficient to control runoff production (Gómez et al., 2003) To be efficient, it should be associated with other measures such as contour farming and terracing to avoid an increase in surface runoff and the occurrence of erosive processes when runoff concentrates (Bertol et al., 2007; Bolliger et al., 2006; Denardin et al., 2008). In addition, the low residue cover of the soil, due to the absence of crop rotation, is insufficient to protect the soil surface against the direct impact of rainfall (Souza et al., 2012).

Few studies have documented the impacts of no-till farming on runoff and erosion at the catchment scale. However, there is a need to better understand the impact of conservation agriculture on the spatial and temporal dynamics of soil degradation and to identify the combination of control measures that would be the most efficient for controlling losses and transfers of water, soil, nutrients and agrochemicals. Accordingly, catchment monitoring and modelling should be combined to design effective strategies to reduce the deleterious impacts of intensive farming. In large catchments (Boix-Fayos et al., 2008), the flow response and sediment concentrations can be monitored and related to rainfall and physiographic characteristics (relief, soil, use and management) in order to identify the main factors controlling runoff and sediment generation and their transfer across the landscape. Models can also be used to simulate the spatial and temporal dynamics of hydrological and erosive processes. They can be either deterministic (Knapen et al., 2007; Nearing et al., 1999; Okoro and Ibearugbulem, 2013) or 
empirical (Foster et al., 2003; Kinnell, 2010) and their performance will depend on the quality of the monitoring data and the availability of the input parameters (Horowitz et al., 2014; Merten et al., 2006). Once they have been calibrated, these models can also be used to simulate the impact of climate change (Nearing et al., 2004), or the effectiveness of various scenarios of conservation practices (Fu et al., 2005; Terranova et al., 2009; Wang et al., 2009) on sediment yields.

Empirical mathematical models based on the Universal Soil Loss Equation (Alatorre et al., 2012; Bezak et al., 2015; Van Oost et al., 2000; Van Rompaey et al., 2001; Verstraeten et al., 2002) and incorporating a transport capacity equation, such as WaTEM/SEDEM (Van Rompaey et al., 2001) provide powerful tools to simulate erosion and sediment transport at the catchment scale (de Vente et al., 2008; Poesen, 2011).

Studies with WaTEM/SEDEM model have generated satisfactory estimations of soil redistribution on hillslopes (de Moor and Verstraeten, 2008; Notebaert et al., 2011; Verstraeten et al., 2009) and sediment yields from catchments (Haregeweyn et al., 2013; Rompaey et al., 2005). The model has been widely used in different topographic, climatic and soil use conditions (Keesstra et al., 2009; Quiñonero-Rubio et al., 2014; Rompaey et al., 2005). However, to the best of our knowledge, this model has never been applied in large catchments of Brazil despite the very high erosion rates occurring in this region of the world.

The objective of the current research is to quantify the impact of conservation measures on spatial variations of runoff and soil erosion in an agricultural catchment under no-till of southern Brazil. Accordingly, the impact of different conservation scenarios will be assessed through the use of a model calibrated based on 5-yrs monitoring data. The need to combine monitoring and modelling will then be discussed to propose the optimal set of 
conservation measures for a sustainable soil and water management in this region of the world.

\section{Material and methods}

\subsection{Study area}

The Conceição catchment is located in the northwest of the southernmost State of Brazil (Rio Grande do Sul). It drains a surface area of $800 \mathrm{~km}^{2}$, and the monitoring station is located at the outlet (coordinates: $28^{\circ} 27^{\prime} 22^{\prime \prime} \mathrm{S}$ and $53^{\circ} 58^{\prime} 24^{\prime \prime} \mathrm{W}$ ). According to Köppen's classification, the climate is of Cfa type, i.e. subtropical humid without dry season, with an average annual rainfall comprised between 1750 and $2000 \mathrm{~mm}$ and an average temperature of $18.6^{\circ} \mathrm{C}$. The geological bedrock is basaltic, and it is overlaid with deep and highly weathered soils (Oxisols, Ultisols, and Alfisols), with the Oxisols being the dominant soil class in the catchment. These soils are enriched in iron oxides and kaolinite. The landscape is characterized by gentle slopes (6-9\%) on the top and on the hillsides, whereas steeper slopes (10-14\%) are found near the drainage channels. The main crops are soybean (Glycine max) during summer and wheat (Triticum spp.), oats (Avena strigosa), and ryegrass (Lolium multiflorum) during winter. The two latter crops provide straw for mulching during summer and these fields may also be used as pasture for dairy cattle. Notillage is applied on $>80 \%$ of the cropland, without the implementation of additional erosion control measures such as terraces, strip cropping, vegetated ridges, or contourfarming. Other land uses including forests, wetlands, and urban areas cover less than $15 \%$ of the total catchment surface area.

\section{Figure 1 - Location of the Conceição river catchment}

The riparian areas found along the permanent river network are narrow $(<10 \mathrm{~m}$ wide) and affected by cattle trampling, which prevents them from providing effective traps to stop sediment originating from upper parts of the catchment. The current land cover 
111 distribution in the catchment was used to define a business-as-usual (BAU) scenario

112 representative of the conditions found in areas dedicated to intensive grain farming in 113 southern Brazil.

114

\subsection{Hydro-sedimentary monitoring}

River monitoring was conducted during a 5-year period, from January 2011 to

December 2015. Rainfall (R), river discharge (Q) and suspended sediment concentrations (SSC) were measured automatically at the catchment outlet every 10-minutes. In addition, manual measurements were made every 30-60 minutes during flood events.

River discharge (Q) was estimated from water level measurements using a

limnigraph at the outlet station, through the conversion of pressure values into flow using the appropriate discharge rating curve calculated for the monitoring section. Consistence of this continuous monitoring data was compared to the daily measurements made by a local observer. SSC dta were acquired in 10-minute intervals indirectly using a turbidimeter. Signals $(\mathrm{mV})$ were converted into NTU by using Polymer bead calibration solutions and the NTU was converted into SSC by using the SSC equation obtained from daily manual samples using a DH-48 sampler (USGS).

Samples collected during flood events were brought back to the Sedimentology Laboratory at the Federal University of Santa Maria, Brazil, to determine SSC after evaporation and filtration of the samples (Shreve and Downs, 2005). In addition to the traditional sampling methods, a turbidity meter was used to increase the frequency of measurements. It was calibrated using SSC data acquired simultaneously, following the method described by (Merten et al., 2006; Minella et al., 2008).

Suspended solid discharge SSD ( kg. $\left.\mathrm{s}^{-1}\right)$ was estimated by multiplying instantaneous $\mathrm{Q}\left(\mathrm{Ls}^{-1}\right)$ and SSC $\left(\mathrm{gL}^{-1}\right)$ data. SSD was then used to calculate sediment yield (SY; t.year $\left.{ }^{-1}\right)$, (Porterfield, 1977). 


\subsection{Modelling erosion processes}

Erosion processes were simulated using the spatially-distributed WaTEM-2000 model (Van Rompaey et al., 2001) developed to estimate water and tillage erosion, sediment deposition and to quantify sediment supply to the river channels. The model is divided into three modules: (I) assessment of annual soil loss using the Revised Universal Soil Loss Equation (RUSLE) (Renard et al, 1997); (II) evaluation of the annual sediment transport capacity (Van Rompaey et al., 2001; Verstraeten et al., 2002), and (III) simulation of the sediment transfer pathway. The annual average of the gross soil erosion $\left(\mathrm{E} ; \mathrm{kg} \mathrm{m}^{-2}\right.$ year $\left.^{-1}\right)$ is calculated for each pixel using Eq. (1):

$$
\mathbf{E}=\mathbf{R} * \mathbf{K} * \mathbf{L S}_{2 \mathrm{D}} * \mathbf{C} * \mathbf{P}
$$

Where $\mathrm{R}$ is the rainfall erosivity factor $\left(\mathrm{MJ} \mathrm{mm} \mathrm{m} \mathrm{m}^{-2} \mathrm{yr}^{-1}\right), \mathrm{K}$ is the soil erodibility factor $\left(\mathrm{kg} \mathrm{h} \mathrm{MJ}{ }^{-1} \mathrm{~mm}^{-1}\right), \mathrm{LS}_{2 \mathrm{D}}$ is a parameter reflecting the slope steepness and length based on the algorithms of Desmet and Govers (1996), and the slope factor $\mathrm{LS}_{2 \mathrm{D}}$ is adjusted using a two-dimensional routing algorithm (Van Oost et al., 2000) to account for rill, inter-rill and gully erosion (Desmet et al., 1999), $\mathrm{C}$ is soil coverage factor (including biomass and mulch depending on soil use and management; (Renard et al, 1997), and P the (optional) soil conservation factor.

Two rainfall monitoring stations from the Water National Agency (ANA) located within the catchment (Fig. 1) with 50-yr records were used to estimate the R factor. Erosivity was calculated with an equation using monthly and annual rainfall developed by Cassol et al., (2007) for Southern Brazil.

Erodibility (factor K) was calculated using equations developed by Roloff \& Denardin (1994) for Brazilian soils. The physical and chemical parameters required to apply the equations were measured in the different soil classes, and their spatial distribution was estimated from the soil map. Acrisols showed the highest susceptibility to erosion with a K 
value of 0.03756 , followed by Nitosols with a K of 0.01752 . Oxisols, which cover approximately $80 \%$ of the catchment surface area, were associated with values ranging from 0.01155 to 0.01590 . This demonstrates that most soils of the catchment show a very high aggregate stability. The physical parameters used to calculate the $\mathrm{K}$ factor were the soil texture, considering the grain size $(0.02 \mathrm{~mm})$, silt $(0.02-0.005 \mathrm{~mm})$ and fine sand $(0.2$ $\left.-0.005 \mathrm{~mm} \mathrm{~g} \mathrm{~g}^{-1}\right)$ as well as the percentage of permeability of each soil type $\left(\mathrm{mm} \mathrm{h}^{-1}\right)$. As for the chemical parameters, the iron $\left(\mathrm{Fe}_{2} \mathrm{O}_{3}\right)$ and aluminum $\left(\mathrm{Al}_{2} \mathrm{O}_{3}\right)$ oxides $\left(\mathrm{g} \mathrm{kg}^{-1}\right)$ were used for each soil class; temporal variability in the $\mathrm{K}$ factor values was not considered, because the paramethers involved in determining the K-factor had not been altered. In order to calculate the topographic factor $\left(\mathrm{LS}_{2 \mathrm{D}}\right)$, the Digital Elevation Model (DEM) was created by interpolating between the contour lines of digital topographic maps with a 20-m resolution. The $\mathrm{LS}_{2 \mathrm{D}}$ factor was calculated based on the algorithm proposed by Desmet and Govers (1996). Considers that gully erosion is not dominant in the Conceição catchment. Only few ephemeral gullies occur in the area. Gully erosion can be found in some locations, but we still do not know how much it contributes to total sediment yield (SY). represent the sediment transport capacity.

Aimming to represent such processes, the Watem Sedem modell uses the LS factor to

In order to represent the transport capacity the modell uses the logarithm of Desmet et al. (1999) and Desmet and Govers (1996), which describes the LS factor and associates the gullies process. The modell incorporates different criteria and uses topographic attributes to indicate the location of the gullies' starting points, flow direction, characteristics of soil surface, vegetation cover, slope gradient and length.

Accordingly, the original transport capacity equation was used (Van Rompaey et al., 2001), which allows the model to represent the connections directly through channels with flow concentration preferential pathways (thalwegs) connecting water and sediment 
flows on hillslopes with the rivers (Verstraeten et al., 2006) and / or interrupt the flows

with either natural or mechanical barriers. The C-factor was determined using the methodology described by (Renard et al., 1997). Crop rotation (C-factor) aims to reduce the direct impact of rainfall events on the soil surface. Annual values of $\mathrm{C}$-factor were attributed according to the land use (cropland, pasture and forest). The spatial distribution of the C-factor for the catchment fields was based on of the analysis of satellite images and field surveys (Table 1$)$. In addition to the BAU conditions $\left(\mathrm{C}_{\mathrm{high}}\right)$, an alternative scenario $\left(\mathrm{C}_{\text {low }}\right)$ was constructed including an increase of crop rotations, with the planting of turnip (winter) and maize (summer) in addition to the traditional soybean and wheat crops. This and the impact of crop rotation on soil loss and the connectivity of sediments to rivers.Table 1 - Values for the soil cover factor (C) simulated for the Conceição River

\section{Catchment.}

\section{* Business-as-usual; C : Factor C, Cs : Soil Cover, Cc : Cover by canopy, PU : Prior} land use, Rs : surface roughness.

The P factor corresponds to the efficiency of conservation measures implemented in the catchment. A value of 1 represents the worst case scenario with the least efficiency (tillage). Currently, no-tillage is the only conservation measure implemented in the catchment. Accordingly, a mean value of 0.8 , which corresponds to a $20 \%$ water retention efficiency, was attributed to the $\mathrm{P}$ factor for the entire catchment. In the study area, crops are usually sown in the direction parallel to the longest field boundary (i.e. typically perpendicular to the contour lines). In order to quantify the potential impact of crop levelling in the catchment, the angle between the contour lines and the sowing rows was measured (mean angle of $45^{\circ}$ ). According to the equation provided by (Renard et al, 1997), 
the sowing efficiency was estimated to 0.20 , which will affect the value of $\mathrm{P}$ for each pixel depending on the local slope. to lower sections of the hillslope until it reaches the permanent drainage network. The amount of sediments transported by surface flow depends on the soil transport capacity (Tc) (Eq. 2), which is controlled by the physiographic factors of the cell considered (Van Rompaey et al., 2001). Tc is the maximum amount of soil that can be transported from a given pixel per length unit to the adjacent pixel, assuming that the transport capacity is proportional to the potential of gully erosion.

$\mathrm{Tc}=\mathrm{ktc} * \mathrm{R} * \mathrm{~K} *\left(\mathrm{LS}_{\mathrm{2D}}-4.12 * \mathrm{~S}_{\mathrm{g}}{ }^{0.8}\right)$

Where: Tc is the transport capacity expressed as $\left(\mathrm{kg} \mathrm{m}^{-1} \mathrm{yr}^{-1}\right)$, $\mathrm{ktc}$ is the coefficient of transport capacity, expressed in m; R, K and $\mathrm{LS}_{2 \mathrm{D}}$ are RUSLE factors (Renard et al, 1997), and $\mathrm{S}_{\mathrm{g}}$ is the steepness of the slope $\left(\mathrm{m} \mathrm{m}^{-1}\right)$.

The transport capacity coefficient Ktc (m) describes the proportionality between the potential for rill erosion and the transport capacity. It can be interpreted as the theoretical

WATEM/SEDEM employs a routing algorithm to transfer the eroded sediment from the source to the river network (Desmet and Govers, 1996; Van Oost et al., 2000). This algorithm was improved by (Haregeweyn et al., 2013). The distribution between soil erosion, transport and deposition processes is controlled by the values of E (Erosion) and Tc (transport capacity): when E> Tc, deposition will occur, whereas there will be sediment transfer when $\mathrm{E}<\mathrm{Tc}$.

\subsection{Model calibration and scenarios}


The calibration parameters were the transport coefficients $\mathrm{Ktc}_{\mathrm{Low}}$ and Ktc $\mathrm{C}_{\text {igh }}$ obtained by minimizing the difference between simulated and measured values. The parameters of plot efficiency (Ptef) in cropland, forests and pastures were 20, 90 and 60, respectively. The parcel connectivity parameter (PC) was set to 20 for cropland and to 60 for forest and pasture. The method described by (Moriasi et al., 2007) was used to quantify the statistical efficiency of the WaTEM/SEDEM model to simulate the sediment yield. measures were modelled, with two sets of rainfall conditions (a dry year [ $R_{\text {low }}$ ] with 1458 $\mathrm{mm}$, corresponding to the situation observed in 2013; vs. a wet year [ $\left.\mathrm{R}_{\text {high }}\right]$ with $2251 \mathrm{~mm}$, corresponding to 2014) to quantify their respective impact on erosion, deposition and sediment yield.

Two physical criteria were used to design the conservation scenarios: they had not to be implemented yet by the farmers in the catchment and they had to limit sediment connectivity within the catchment. The selected scenarios incorporate the vegetative and mechanical practices for erosion control. The chosen vegetative practices (different rotations) involve economic criteria, since that is the criteria most often used when farmers implement parcial conservation measures. With this criteria in mind, there are more effective practices that could be implemented maintaining their medium to long-term financial expectations. The mechanical practices (terraces, areas of permanent forest preservation) were chosen considering their ability to control surface runoff and increase soil surface friction, thus, reducing the speed of the water flow. since such measures are currently not present in the selected catchment. Five scenarios were modelled including a 
business-as-usual (BAU) scenario representing current land use and management conditions and four alternative soil conservation scenarios (Table 2):

Table 2: Scenarios modelled in the Conceição River catchment.

(BAU) business-as-usual scenario: Chigh; Scenario I: Clow; Scenario II: Clow + CL + T; Scenario III: Clow + CL + T + APP; Scenario IV: Clow + APP. Where: CL : crop levelling; T: terracing; APP : areas of permanent forest preservation.

It should be noted that the Brazilian Forestry Code legislation determines that certain zones in the catchment should be considered as areas of permanent forest preservation (APP) because of their importance for protecting the environment and the quality of water resources. These include areas adjacent to rivers or natural and artificial reservoirs, and hillslope sections with slope angles steeper than $45^{\circ}$. Removal of the vegetation in these areas is only allowed in certain occasions (e.g. social interest), provided previous authorization is obtained from the appropriate environmental agencies.

\section{Results}

\section{1 Hydrology and sediment yield}

Figure 2 shows the rainfall variability and erosivity from 2011 to 2015 . The monitoring period was heterogeneous, with long periods of drought in 2012 and periods of concentrated rainfall in 2011, 2014 and 2015. In contrast, 2013 was characterized by a rainfall amount close to the long-term average, despite the occurrence of rainfall events of low-to-medium intensity and storms of extreme magnitude. The high intensity rainfall observed in November and December 2015 is attributed to the El Niño phenomenon (Marengo et al., 2009). This rainfall distribution affected the hydrological conditions in the river and the resulting sediment fluxes. The highest sediment fluxes were observed during the years characterized by the highest water discharges (Table 3). 

the monitoring period (2011to 2015).

Table 3 - Representation of hydro-sedimentological variables of the Conceição River catchment for the monitoring period (2011to 2015).

R: rainfall (mm); SSD: suspended sediment discharge; Q: Flow rate $\left(\mathrm{m}^{3} \mathrm{~s}^{-1}\right), \mathrm{SY}$ :

Sediment yield (t. $\left.\mathrm{km}^{-2}\right)$ ); EI30 (MJ mm ha-1 $\left.\mathrm{h}^{-1}\right)$.

290

exhibited large seasonal variations controlled by rainfall distribution (R) and agricultural practices affecting the sensitivity of soils to runoff and erosion (Figure 3). discharges, runoff and sediment yield is demonstrated.

Figure 3 - Monthly averages (2011-2015) of sediment yield (SY), Flow (Q), rainfall (R) for the Conceição River catchment.

\subsection{Model efficiency analysis}

The model and the transport capacity coefficient (Ktc) were initially calibrated considering the entire dataset covering the five years of monitoring ( $\mathrm{SY}_{\mathrm{A}}$ - Table 4$)$. The performance of the model measured by the efficiency index (SE- Statistical Efficiency) was $40 \%$. When excluding 2015 from the calibration data (SY - Table 4), the efficiency of the model increased by $20 \%$, to $60 \%$. This is likely due to the atypical climate conditions observed in 2015, with the occurrence of several extreme events that likely modified the transport capacity and mobilized distinct sediment sources (e.g. channel banks, roads).

The correspondence between the measured and the simulated mean annual SY $\left(\mathrm{t} . \mathrm{km}^{-2}\right.$ year $\left.^{-1}\right)$ for a 5-year period using the WaTEM/SEDEM model is shown in Figure 4. 
Figure 4 - Performance of the WaTEM / SEDEM model in predicting sediment yield (SY) for Conceição River.

$$
\text { When restricting the calibration period to 2011-2014, the optimized PC and }
$$

KTc_Low values were 60 and 0.12 for forests and pastures, and 20 and 0.36 for cropland, respectively. The results of the simulations performed after the calibration are presented in Table 4.

Table 4 - Representation of calibration from sediment yield at the monitoring station and efficiency of the model.

\section{Where: EI 30 : Erosivity (MJ mm ha $\left.{ }^{-1} h^{-1}\right)$, SY : Sediment yield (t.km²): Sub index}

\section{A:four year database (from 2011 to 2014) and B : five year database (from 2011 to} 2015).

\subsection{Modelling alternative soil conservation scenarios}

Sediment yields were simulated for the BAU conditions and the four alternative land cover scenarios (Table 5). Scenario I simulating the implementation of crop rotation with plants providing higher biomass densities to protect the soils reduced only erosion by $0.6 \%$ and sediment yield by $1 \%$ compared to the BAU scenario. Scenario II included crop rotation as well as crop levelling and terracing, and reduced erosion by $358 \%$, deposition by $316 \%$ and sediment yield by $400 \%$. Scenario III combined the conservation measures implemented in scenario II and areas of permanent forest preservation. It was the most effective, with a reduction of soil erosion by $378 \%$, a decrease of sediment deposition by $274 \%$ and of sediment yield by $541 \%$. Scenario IV combined the introduction of crop rotation and permanent forest preservation areas and led to a decrease of only $6.8 \%$ in erosion and of approximately $38 \%$ in sediment yield. Furthermore, this was the only scenario associated with an increase of sediment deposition rates (14\%). 
Table 5 - Results of erosion, sediment deposition and sediment yield estimated by the

\section{WaTEM-SEDEM model for the different scenarios.}

*data set from 2013, representative of a dry year with cumulative rainfall lower than the long-term average $(1458 \mathrm{~mm})$;

**data set from 2014, representative of a wet year with cumulative rainfall above the long-term average $(2251 \mathrm{~mm})$.

Overall, all simulated processes (erosion, deposition and sediment yield) were 33.9\% higher under wet conditions $\left(\mathrm{R}_{\text {high }}\right)$ than under dry conditions $\left(\mathrm{R}_{\text {low }}\right.$; Figure 5$)$.

Figure 5 - Results of erosion, sediment deposition and sediment yield estimated by the WaTEM-SEDEM model for the different scenarios simulated for Rlow and Rhigh.

Figure 6 shows the spatial pattern of soil losses within the Conceição catchment, illustrating the important role played by topography (including slope length, steepness and curvature) to explain spatial variations of erosion. The interactions of the LS factor with the other RUSLE parameters are determined automatically by the WaTEM/SEDEM model. The topographic attributes (LS) also consider the interactions of the soil surface and the vegetation cover ( $\mathrm{C}$-factor), as well as the flow direction, which can be altered and/or controlled through the mechanical practices (P-factor). Based on criterion such as interventions in $\mathrm{C}$ factor values with increased plant biomass as well as factor $\mathrm{P}$. Values for both $\mathrm{C}$ and $\mathrm{P}$ factors were used to verify the responses of the different levels of intervention on the values of soil losses and river connectivity.

Large volumes of runoff and sediment may accumulate on the long convex hillslopes of the catchment and concentrate when reaching the river system, which exposes the lower third section of the slopes to higher erosion rates.Figure 6 - Spatial representation of the erosion of the Conceição River catchment, according to the 
D) Scenario III: $\mathrm{C}_{\text {low }}+\mathrm{CL}+\mathrm{T}+\mathrm{APP}$; E) Scenario IV: $\mathrm{C}_{\text {low }}+$ APP. Where: CL: crop levelling; T: terracing; APP: areas of permanent forest preservation.

\section{Discussion}

\subsection{Effectiveness of land cover scenarios to control soil erosion and sediment yield}

A comparison of the results of all scenarios for both dry $\left(\mathrm{R}_{\text {low }}\right)$ and wet $\left(\mathrm{R}_{\text {high }}\right)$ conditions shows that scenario III is the most efficient in reducing the intensity of erosion and sediment transfer processes. Among the measures included in this scenario, the mechanical conservation measures (simulated in both scenarios II and III) are likely the most effective as they lead to a three-fold decrease of soil loss and sediment yields. In contrast, the introduction of a crop rotation alone (scenario I) does not provide significant erosion control. Results comparable to those obtained for scenario II are simulated for scenario III, including the implementation of APPs. The contribution of APPs alone, without the association with mechanical measures, is simulated in scenario IV. The model indicates the relatively low efficiency of this scenario to control erosion processes, although it is the single set of conditions leading to a $14 \%$ increase in sediment deposition.

This result illustrates the reduction of sediment velocity and the greater retention of sediment in the APPs. Previous studies demonstrated that riparian vegetation leads to a drastic decrease of sediment delivery (Cooper et al., 1987; Verstraeten et al., 2006). However, when applied without the implementation of additional measures to control sediment production at the source, this strategy is found not to be efficient in controlling erosion (less than $10 \%$ reduction when compared to the BAU scenario), as cropland was shown to provide the main source of sediment in this catchment (Tiecher et al., 2014).

\subsection{Impact of land cover scenarios on sediment connectivity}



link between the sediment produced on the hillslopes and the material transiting the river (Croke et al., 2005). In particular, the implementation of forest preservation areas in zones of flow convergence or in the alluvial plains decreases sediment connectivity (QuiñoneroRubio et al., 2014). For instance, a change in land use in targeted zones through the reforestation in fragile areas (Rompaey and Govers, 2002) may have an immediate impact and reduce gross erosion and sediment connectivity (Alatorre et al., 2012). When implementing APPs in the catchment, the model simulated a $38 \%$ reduction in sediment yield and a 14\% increase in sediment deposits (fig. 5), although it had limited impact on gross erosion. The large heterogeneities in sediment connectivity simulated in the catchment may reflect the spatial pattern of the conservation measures implemented in the region (e.g. location of terraces; Fig. -6) or the intensity of rainfall events. Sediment connectivity varies according to the intensity of the monthly and annual rainfall events. Acccordingly, sediment flows are heterogeneous over time. As found in other regions of the world, the highest sediment connectivity between hillslopes and rivers is achieved during the most intense events (e.g. during typhoons in Asia) (Chartin et al., 2016). The lower efficiency of the WaTEM/SEDEM model during the most intense events may be explained by the fact that roads and channels were not taken into account by the model, and their inclusion in the future should improve the quality of the model results during these intense storms.

\subsection{Improvement of soil conservation in Southern Brazil}

The scenario simulations demonstrated that there is a need to combine erosion control measures on the cultivated fields (e.g. implementation of crop rotations, increase of the vegetation cover of the soils) to reduce soil loss at the source, with additional measures reducing sediment connectivity between hillslopes and rivers. The catchment is 
characterized by the intensive soybean/wheat monoculture, which limits the diversity of crops characterized by contrasting growing stages. In Europe, the variety of crops found on a hillslope may create heterogeneous landscape mosaics, with bare soils producing runoff/sediment and zones densely covered by vegetation that may reinfiltrate runoff and trap sediment (Evrard et al., 2007; Souchère et al., 2005). The main soil characteristics controlling runoff and sediment production at the field scale (i.e., soil cover by vegetation, soil roughness, crusting stage) generally vary throughout the year, as a result of plant growth, weather conditions and farming practices (Cerdan et al., 2002; Evrard et al., 2008a). In southern Brazil, the most sensitive periods for runoff and erosion are winter and spring, during the plant initial growth stage or after the harvest, when rainfall is the most abundant (Figure 3). The modelled scenarios showed that soil cover by vegetation is not sufficient during these periods to control erosion (Figure 5; Table 5), and it should be increased to better protect the soils and further limit runoff/sediment production (Reicosky, 2015).

In addition, measures aimed to reducing sediment connectivity will act as a physical barrier and prevent the sediment from reaching the water bodies when they are located on the main runoff/sediment flow pathways (Boix-Fayos et al., 2008). Specific plantation patterns (e.g. crop levelling, contour ploughing) can reduce sediment connectivity (Karlen et al., 2009). Species such as elephant (Pennisetum purpureum), vetiver (Chrysopogon zizanioides) and lemon grasses (Cymbopogon citratus) were shown to provide effective sediment retention traps when planted in thalwegs or in concentrated flow areas (Fiener and Auerswald, 2003; Verstraeten et al., 2002). An alternative to the planting of specific vegetation species could be the installation of small earthen dams in the thalwegs in order to slow down runoff and trap sediment. In Europe, these measurements were shown to reduce sediment yield by 90\% (Evrard et al., 2008a; Evrard 
et al., 2008b). Importantly, there is a need to coordinate the implementation of these

control measures, both at the source and on the main flow pathways, at the catchment scale in order to increase their effectiveness, as it was illustrated in regions of Northwestern

Europe where this type of measures was monitored in pilot areas (Evrard et al., 2010).

\subsection{Perspectives for future research}

Despite the widespread use of no-till in Southern Brazil, soil erosion and sediment transfer remain excessive. Additional measures should be taken to improve this situation, through the implementation of mechanical conservation measures, the increase of biomass cover density of the soil, and the decrease of traffic of agricultural machinery to increase vs. no-till in a $20-\mathrm{km}^{2}$ catchment of Southern Brazil characterized by similar soil characteristics, relief and land use as the study site investigated by the current research (Castro et al., 1999). These authors showed that the runoff coefficient was higher when applying no-till alone $(7.7 \%)$ than when combining the use of conventional tillage and terraces $(5.8 \%)$. Other studies used the sediment fingerprinting technique to quantify the sources supplying sediment to river systems of Southern Brazil. They showed that soils found in lower parts of the catchment, cultivated with conventional practices on steep slopes, were the main source of sediment to the Guaporé River network (Le Gall et al., 2017). In contrast, soils found in upper parts of the catchment, cultivated with soybean under direct sowing, deposited in ponds or in riparian areas before reaching the outlet. This demonstrates the effectiveness of a strategy combining measures at the source and physical barriers along the main flow pathways in the catchment.

Although models can provide powerful helping-decision tools for environmental management, their use depends on the availability of large input datasets for calibration 
455 (Tab.4). In the future, other soil erosion models such as STREAM (Cerdan et al., 2002),

456 APEX (Williams et al., 2008), or SWAT (Williams and Arnold, 1997) could be used to

457 investigate the impact of climate change on the effectiveness of conservation measures.

458 The magnitude and the frequency of heavy storms are expected to increase, which should

459 modify the production and the transfer of sediment across the landscape. The analysis of

460 sediment (dis)connectivity impact by these changes in interaction with the implementation

461 of contrasted conservation scenarios could usefully be tested in order to protect soil and

462 water resources and to allow their sustainable use for agriculture production.

4635 Conclusions

Sediment fluxes were monitored from 2011 to 2015 in the Conceição catchment, representative of cultivated environments under no-till in Southern Brazil. Very high sediment yields, characterized by strong inter-annual variations $\left(37-259 \mathrm{t} \mathrm{km}^{-2} \mathrm{yr}^{-1}\right)$, were measured at the catchment outlet. These results illustrate that the use of no-tillage alone is not sufficient to control soil erosion in this region. The WaTEM/SEDEM erosion model was calibrated and validated with the unique dataset obtained in Conceição, and was subsequently used to simulate contrasted land cover scenarios in order to propose a sustainable use of soil resources in this intensively cultivated region. The combination of direct sowing with measures recommended by the conservation agriculture principles (e.g. increase in biomass cover of the soil, crop rotation, physical barriers) was shown to lead to a 3-to-5 fold reduction of soil loss and sediment yields in this region. Model simulations demonstrated in particular the need to implement mechanical measures and to preserve riparian forests to slow down runoff and trap

477 sediment. This integrated soil conservation strategy should be tested in these environments of Southern Brazil, in order to promote sustainable farming practices and to prevent the

479 further degradation of water quality. 


\section{Acknowledgements}

The research benefited from the support of the CAPES-COFECUB project no Te870-15.

\section{References}

Alatorre, L.C., Beguería, S., Lana-Renault, N., Navas, A., García-Ruiz, J.M., 2012. Soil erosion and sediment delivery in a mountain catchment under scenarios of land use change using a spatially distributed numerical model. Hydrol. Earth Syst. Sci. 16, 1321-1334. doi:10.5194/hess-16-1321-2012

Bertol, I., Cogo, N.P., Schick, J., Gudagnin, J.C., Amaral, A.J., 2007. Aspectos financeiros relacionados às perdas de nutrientes por erosão hídrica em diferentes sistemas de manejo do solo. Rev. Bras. Ciência do Solo 31, 133-142. doi:10.1590/S010006832007000100014

Bezak, N., Rusjan, S., Petan, S., Sodnik, J., Mikoš, M., 2015. Estimation of soil loss by the WATEM/SEDEM model using an automatic parameter estimation procedure. Environ. Earth Sci. doi:10.1007/s12665-015-4534-0

Boix-Fayos, C., De Vente, J., Martínez-Mena, M., Barberá, G.G., Castillo, V., 2008. The impact of land use change and check-dams on catchment sediment yield 22, 49224935. doi:10.1002/hyp.7115

Bolliger, A., Magid, J., Amado, J.C.T., Skóra Neto, F., Ribeiro, M. de F. dos S., Calegari, A., Ralisch, R., de Neergaard, A., 2006. Taking Stock of the Brazilian "Zero-Till Revolution": A Review of Landmark Research and Farmers' Practice. Adv. Agron. 91, 47-110. doi:10.1016/S0065-2113(06)91002-5

Cassol, E.A., Martins, D., Luiz, F., Eltz, F., Lima, V.S. De, 2007. Erosividade e padroes hidrologicos das chuvas de Ijui ( RS ) no periodo de 1963 a 1993 Erosivity and hydrological patterns of Ijui ( RS , Brazil ) rainfalls in the period of 1963 to 1993. 
Rev. Bras. Agrometeorol. 15, 220-231.

506

507

508

509

510

511

512

513

514

515

516

517

518

519

520

521

522

523

524

525

526

527

528

529

Castro, N.M.D.R., Auzet, A.-V., Chevallier, P., Leprun, J.-C., 1999. Land use change effects on runo and erosion from plot to catchment scale on the basaltic plateau of Southern Brazil. Hydrol. Process. 13, 1621-1628.

Cerdan, O., Souchère, V., Lecomte, V., Couturier, A., Le Bissonnais, Y., 2002. Incorporating soil surface crusting processes in an expert-based runoff model: Sealing and Transfer by Runoff and Erosion related to Agricultural Management. CATENA 46, 189-205. doi:10.1016/S0341-8162(01)00166-7

Chartin, C., Evrard, O., Laceby, J.P., Onda, Y., Ottlé, C., Lefèvre, I., Cerdan, O., 2016. The impact of typhoons on sediment connectivity: Lessons learnt from contaminated coastal catchments of Fukushima Prefecture (Japan). Earth Surface Processes and Landforms. DOI: 10.1002/esp.4056.

Cooper, J.R., Gilliam, J.W., Daniels, R.B., Robarge, W.P., 1987. Riparian areas as filters for agricultural sediment. Soil Sci. Soc. Am. J.

Croke, J., Mockler, S., Fogarty, P., Takken, I., 2005. Sediment concentration changes in runoff pathways from a forest road network and the resultant spatial pattern of catchment connectivity 68, 257-268. doi:10.1016/j.geomorph.2004.11.020

de Moor, J.J.W., Verstraeten, G., 2008. Alluvial and colluvial sediment storage in the Geul River catchment (The Netherlands) — Combining field and modelling data to construct a Late Holocene sediment budget. Geomorphology 95, 487-503. doi:10.1016/j.geomorph.2007.07.012

Denardin, J.E., Kochhann, R.A., Faganello, A., Sattler, A., Manhago, D.D., 2008. "Vertical mulching" como prática conservacionista para manejo de enxurrada em sistema plantio direto. Rev. Bras. Ciência do Solo 32, 2847-2852. doi:10.1590/S010006832008000700031 
Derpsch, R., Franzluebbers, A.J., Duiker, S.W., Reicosky, D.C., Koeller, K., Friedrich, T., Sturny, W.G., Sá, J.C.M., Weiss, K., 2014. Why do we need to standardize no-tillage research? Soil Tillage Res. doi:10.1016/j.still.2013.10.002

Desmet, P.J.J., Govers, G., 1996. A GIS procedure for automatically calculating the USLE LS factor on topographically complex landscape units. J. Soil Water Conserv. 51, $427-433$.

Desmet, P.J.J., Poesen, J., Govers, G., Vandaele, K., 1999. Importance of slope gradient and contributing area for optimal prediction of the initiation and trajectory of ephemeral gullies.

Evrard, O., Heitz, C., Liégeois, M., Boardman, J., Vandaele, K., Auzet, A.-V., van Wesemael, B., 2010. A comparison of management approaches to control muddy floods in central Belgium, northern France and southern England. L. Degrad. Dev. 21, 322-335. doi:10.1002/ldr.1006

Evrard, O., Persoons, E., Vandaele, K., Wesemael, B. Van, 2007. Effectiveness of erosion mitigation measures to prevent muddy floods : A case study in the Belgian loam belt 118, 149-158. doi:10.1016/j.agee.2006.02.019

Evrard, O., Vandaele, K., van Wesemael, B., Bielders, C.L., 2008a. A grassed waterway and earthen dams to control muddy floods from a cultivated catchment of the Belgian loess belt. Geomorphology 100, 419-428. doi:10.1016/j.geomorph.2008.01.010

Evrard, O., Vandaele, K., Wesemael, B. Van, Bielders, C.L., 2008b. A grassed waterway and earthen dams to control muddy floods from a cultivated catchment of the Belgian loess belt 100, 419-428. doi:10.1016/j.geomorph.2008.01.010

Fiener, P., Auerswald, K., 2003. Effectiveness of Grassed Waterways in Reducing Runoff and Sediment Delivery from Agricultural Watersheds. J. Environ. Qual. 32, 927. doi:10.2134/jeq2003.9270 
Foster, G.R., Toy, T.E., Renard, K.G., 2003. Comparison of the USLE, RUSLE1.06c, and RUSLE2 for Application to Highly Disturbed Lands. USDA-ARS 154-160.

Fu, B.J., Zhao, W.W., Chen, L.D., Zhang, Q.J., Lü, Y.H., Gulinck, H., Poesen, J., 2005. Assessment of soil erosion at large watershed scale using RUSLE and GIS: A case study in the Loess Plateau of China. L. Degrad. Dev. doi:10.1002/ldr.646

Le Gall, M., Evrard, O., Dapoigny, A., Tiecher, T., Zafar, M., Paolo, J., Minella, G., Laceby, J.P., Ayrault, S., 2017. Tracing sediment sources in a subtropical agricultural catchment of southern Brazil cultivated with conventional and conservation farming practices. L. Degrad. Dev. DOI: 10.1002/ldr.2662

Gómez, J.A., Battany, M., Renschler, C.S., Fereres, E., 2003. Evaluating the impact of soil management on soil loss in olive orchards. Soil Use Manag. 19, 127-134. doi:10.1111/j.1475-2743.2003.tb00292.x

Haregeweyn, N., Poesen, J., Verstraeten, G., Govers, G., Vente, J.D.E., Nyssen, J., Deckers, J., Moeyersons, J., 2013. Assessing the performance of a spatially distributed soil erosion and sediment delivery model ( WaTEM / SEDEM ) IN 204, $188-204$.

Horowitz, A.J., Elrick, K.A., Smith, J.J., Stephens, V.C., 2014. The effects of Hurricane Irene and Tropical Storm Lee on the bed sediment geochemistry of U.S. Atlantic coastal rivers. Hydrol. Process. 28, 1250-1259. doi:10.1002/hyp.9635

Karlen, D.L., Dinnes, D.L., Tomer, M.D., Meek, D.W., Cambardella, C.A., Moorman, T.B., 2009. Is No-Tillage Enough ? A Field-Scale Watershed Assessment of Conservation Effects 7, 1-24.

Keesstra, S.D., van Dam, O., Verstraeten, G., van Huissteden, J., 2009. Changing sediment dynamics due to natural reforestation in the Dragonja catchment, SW Slovenia. CATENA 78, 60-71. doi:10.1016/j.catena.2009.02.021 
580

581

582

583

584

585

586

587

588

589

590

591

592

593

594

595

596

597

598

599

600

601

602

603

604

Kinnell, P.I.A., 2010. Event soil loss, runoff and the Universal Soil Loss Equation family of models: A review. J. Hydrol. 385, 384-397. doi:10.1016/j.jhydrol.2010.01.024

Knapen, A., Poesen, J., Govers, G., Gyssels, G., Nachtergaele, J., 2007. Resistance of soils to concentrated flow erosion: A review. Earth-Science Rev. 80, 75-109. doi:10.1016/j.earscirev.2006.08.001

Lal, R., 2007. Constraints to adopting no-till farming in developing countries. Soil Tillage Res. 94, 1-3. doi:10.1016/j.still.2007.02.002

Lal, R., Delgado, J.A., Gulliford, J., Nielsen, D., Rice, C.W., Pelt, R.S. Van, 2012. extreme events 67, 162-166. doi:10.2489/jswc.67.6.162A

Marengo, J.A., Jones, R., Alves, L.M., Valverde, M.C., 2009. Future change of temperature and precipitation extremes in South America as derived from the PRECIS regional climate modeling system 2255, 2241-2255. doi:10.1002/joc

Merten, G.H., Horowitz, A., Clarke, R., Minella, J., Pickbrenner, K., Pinto, M., 2006. Considerações sobre a utilização da curva-chave para determinação de fluxo de sedimentos - Quantificação das incertezas nas estimativas do fluxo de sedimentos em suspensão, gerados a partir de uma curva-chave.

Minella, J.P.G., Merten, G.H., Reichert, J.M., Clarke, R.T., 2008. Estimating suspended sediment concentrations from turbidity measurements and the calibration problem. Hydrol. Process. 22, 1819-1830. doi:10.1002/hyp.6763

Montgomery, D.R., 2007. Soil erosion and agricultural sustainability. Proc. Natl. Acad. Sci. U. S. A. 104, 13268-72. doi:10.1073/pnas.0611508104

Moriasi, D.N., Arnold, J.G., Liew, M.W. Van, Bingner, R.L., Harmel, R.D., Veith, T.L., 2007. M e g s q a w s 50, 885-900.

Nearing, M.A., Govers, G., Norton, L.D., 1999. Variability in Soil Erosion Data from Replicated Plots. Soil Sci. Soc. Am. J. 63, 1829. doi:10.2136/sssaj1999.6361829x 
Nearing, M., Pruski, F.F., O’Neal, M.R., 2004. Expected climate change impacts on soil erosion rates: A review. J. Soil Water Conserv. 59, 43-50.

Notebaert, B., Verstraeten, G., Ward, P., Renssen, H., Rompaey, A. Van, 2011. Geomorphology Modeling the sensitivity of sediment and water runoff dynamics to Holocene climate and land use changes at the catchment scale 126, 18-31. doi:10.1016/j.geomorph.2010.08.016

Okoro, B.C., Ibearugbulem, 2013. Gully Erosion Control along NWORIE River in Owerri, InImo State-A Deterministic Model Approach. Ijmer 3, 1774-1782.

Poesen, J., 2011. Challenges in gully erosion research 17, 5-9.

Porterfield, 1977. Computation of fluvial-sediment discharge.

Quiñonero-Rubio, J.M., Nadeu, E., Boix-Fayos, C., de Vente, J., 2014. Evaluation of the Effectiveness of Forest Restoration and Check-Dams to Reduce Catchment Sediment Yield. L. Degrad. Dev. 27, 1018-1031. doi:10.1002/ldr.2331

Reicosky, D.C., 2015. Conservation tillage is not conservation agriculture. J. Soil Water Conserv. 70, 103A-108A. doi:10.2489/jswc.70.5.103A

Renard et al, 1997. Predicting Soil Erosion by Water: A Guide to Conservation Planning with the Revised Universal Soil Loss Equation (RUSLE), 703rd ed. Washington, DC.

Roloff, G \& Denardin, JE (1994). Estimativa simplificada da erodibilidade do solo. In. Reunião Brasileira de Manejo e Conservação do Solo e da Água, Florianópolis. $10^{\circ}$, Anais. Florianópolis: Sociedade Brasileira de Ciência do Solo. p.150-151.

Rompaey, A. Van, Bazzoffi, P., Jones, R.J.A., Montanarella, L., 2005. Modeling sediment yields in Italian catchments. Geomorphology 65, 157-169. doi:10.1016/j.geomorph.2004.08.006

Rompaey, A.J.J. Van, Govers, G., n.d. Data quality and model complexity for regional scale soil erosion prediction. Int. J. Geogr. Inf. Sci. 16, 663-680. 
Shreve, E.A., Downs, A.C., 2005. Quality-Assurance Plan for the Analysis of Fluvial Sediment by the U.S. Geological Survey Kentucky Water Science Center Sediment Laboratory.

Souza, C.M. de; Pires, F.R.; Partelli, F.L.; Assis, R.L. de Adubação verde e rotação de culturas. Viçosa: Ed. UFV, 2012.108p.

Souchère, V., Cerdan, O., Dubreuil, N., Le Bissonnais, Y., King, C., 2005. Modelling the impact of agri-environmental scenarios on runoff in a cultivated catchment

(Normandy, France). CATENA 61, 229-240. doi:10.1016/j.catena.2005.03.010

Terranova, O., Antronico, L., Coscarelli, R., Iaquinta, P., 2009. Soil erosion risk scenarios in the Mediterranean environment using RUSLE and GIS: An application model for Calabria (southern Italy). Geomorphology 112, 228-245. doi:10.1016/j.geomorph.2009.06.009

Tiecher, T., Paolo, J., Minella, G., Miguel, P., Rasche, J.W., Pellegrini, A., Capoane, V., Ciotti, L.H., Luiz, G., 2014. Contribuição das fontes de sedimentos em uma bacia hidrográfica agrícola sob plantio direto. 639-649.

Van Oost, K., Govers, G., Desmet, P., 2000. Evaluating the effects of changes in landscape structure on soil erosion by water and tillage. Landsc. Ecol.

doi:10.1023/A:1008198215674

Van Rompaey, A.J.J., Verstraeten, G., Van Oost, K., Govers, G., Poesen, J., 2001. Modelling mean annual sediment yield using a distributed approach. Earth Surf. Process. Landforms. doi:10.1002/esp.275

Vente, J. De, Poesen, J., Verstraeten, G., 2008. Spatially distributed modelling of soil erosion and sediment yield at regional scales in Spain 60, 393-415. doi:10.1016/j.gloplacha.2007.05.002

Verstraeten, G., Oost, K. Van, Rompaey, A. Van, Poesen, J., Govers, G., 2002. Evaluating 

an integrated approach to catchment management to reduce soil loss and sediment pollution through modelling. Soil Use Manag. 19, 386-394.

657 doi:10.1079/SUM2002150

658

Verstraeten, G., Poesen, J., Gillijns, K., Govers, G., 2006. The use of riparian vegetated filter strips to reduce river sediment loads : an overestimated control measure ? 4267, 4259-4267. doi:10.1002/hyp.6155

661

Verstraeten, G., Rommens, T., Peeters, I., Poesen, J., Govers, G., Lang, A., 2009. A

662 temporarily changing Holocene sediment budget for a loess-covered catchment

663 (central Belgium). Geomorphology 108, 24-34. doi:10.1016/j.geomorph.2007.03.022

664

665

666

667

668

669

670
Wang, G., Hapuarachchi, P., Ishidaira, H., Kiem, A.S., Takeuchi, K., 2009. Estimation of Soil Erosion and Sediment Yield During Individual Rainstorms at Catchment Scale. Water Resour. Manag. 23, 1447-1465. doi:10.1007/s11269-008-9335-8

Williams, J.R., Arnold, J.G., 1997. A system of erosion-sediment yield models 11, 43-55.

Williams, J.R., Arnold, J.G., Kiniry, J.R., Gasaman, P.W., Green, C.H., 2008. History of model development at Temple, Texas. Hydrol. Sci. J. 53, 948-960.

doi:10.1623/hysj.53.5.948 
Table 1 - Values for the soil cover factor (C) simulated for the Conceição River Catchment.

\begin{tabular}{lccccc}
\hline & C & Cs & Cc & PU & Rs \\
\hline $\mathrm{C}_{\text {high }}:$ Soybean/Fallow/Wheat/Soybean* & 0.01794 & 0.122 & 0.576 & 0.236 & 0.980 \\
\hline Clow: Soybean/Turnip/Corn/Wheat 0.01260 & 0.106 & 0.529 & 0.170 & 0.969 \\
\hline
\end{tabular}

* Business-as-usual; $\mathrm{C}=$ Factor $\mathrm{C}, \mathrm{Cs}=$ Soil Cover, $\mathrm{Cc}=$ Cover by canopy, $\mathrm{PU}=$ Prior land use, Rs = surface roughness. 
Table 2: Scenarios modelled in the Conceição River catchment.

\begin{tabular}{ccccc}
\hline Scenarios & Factor C & \multicolumn{3}{c}{ Additional conservation measure } \\
\hline BAU & $\mathrm{C}_{\text {high }}$ & - & - & - \\
Scenario I & $\mathrm{C}_{\text {low }}$ & - & - & - \\
Scenario II & $\mathrm{C}_{\text {low }}$ & $\mathrm{CL}$ & $\mathrm{T}$ & - \\
Scenario III & $\mathrm{C}_{\text {low }}$ & $\mathrm{CL}$ & $\mathrm{T}$ & APP \\
Scenario IV & $\mathrm{C}_{\text {low }}$ & APP & - & - \\
\hline
\end{tabular}

(BAU) business-as-usual scenario: $\mathrm{C}_{\text {high }}$; Scenario I: $\mathrm{C}_{\text {low }}$; Scenario II: $\mathrm{C}_{\text {low }}+\mathrm{CL}+\mathrm{T}$;

Scenario III: $\mathrm{C}_{\text {low }}+\mathrm{CL}+\mathrm{T}+\mathrm{APP}$; Scenario IV: $\mathrm{C}_{\text {low }}+$ APP. Where: CL: crop leveling;

T: terracing; APP: areas of permanent forest preservation. 
Table 3 - Representation of hydrossedimentological variables of the Conceição River catchment for the monitoring period (2011 to 2015).

\begin{tabular}{cccccccc}
\hline & $\mathrm{R}$ & $\mathrm{El}_{30}$ & \multicolumn{2}{c}{$\mathrm{SSD}\left(\mathrm{kg} \mathrm{s}^{-1}\right)$} & $\mathrm{Q}\left(\mathrm{m}^{3} \mathrm{~s}^{-1}\right)$ & $\mathrm{SY}$ \\
\hline Year & & & Mean & Maximum & Mean & Maximum & \\
\hline 2011 & 2135 & 11222 & 2.58 & 423.5 & 24.2 & 998.3 & 119.5 \\
2012 & 1632 & 9476 & 1.53 & 264.7 & 13.4 & 541.2 & 73.6 \\
2013 & 1458 & 8164 & 0.73 & 57.5 & 18.6 & 488 & 36.8 \\
2014 & 2251 & 12129 & 1.72 & 365.3 & 31.6 & 1442.8 & 154.4 \\
2015 & 2470 & 12368 & 2.14 & 457.39 & 35.9 & 1051.7 & 259.1 \\
\hline
\end{tabular}

R: rainfall (mm); SSD: suspended sediment discharge; Q: Flow rate $\left(\mathrm{m}^{3} \mathrm{~s}^{-1}\right), \mathrm{SY}$ :

Sediment yield (t. km $\left.{ }^{-2}\right)$; $\mathrm{EI}_{30}(\mathrm{MJ}$ mm ha-1 h-1). 
Table 4 - Representation of calibration from sediment yield at the monitoring station and efficiency of the model.

\begin{tabular}{ccccc}
\hline & & & $\mathrm{SY}_{\mathrm{A}}\left(\mathrm{t} . \mathrm{km}^{-2} \mathrm{yr}^{-1}\right)$ & $\mathrm{SY}_{\mathrm{B}}\left(\mathrm{t} . \mathrm{km}^{-2} \mathrm{yr}^{-1}\right)$ \\
& & & $\mathrm{NS}=0.57$ & $\mathrm{NS}=0.40$ \\
\hline Year & $\mathrm{EI}_{30}$ & Measured & Simulated & Simulated \\
\hline 2011 & 11222 & 119.5 & 107.5 & 120.6 \\
2012 & 9476 & 73.6 & 87.5 & 98.1 \\
2014 & 8164 & 36.8 & 37.9 & 84.5 \\
2015 & 12129 & 154.4 & 114.1 & 127.9 \\
& 12368 & 259.1 & 119.5 & 134.1 \\
\hline
\end{tabular}

Where: $\mathrm{EI}_{30}$ : Erosivity $\left(\mathrm{MJ} \mathrm{mm} \mathrm{ha}^{-1} \mathrm{~h}^{-1}\right), \mathrm{SY}$ : Sediment yield $\left(\mathrm{t} . \mathrm{km}^{-2}\right)$ : Sub index A:four year database (from 2011 to 2014) and B : five year database (from 2011 to 2015). 
Table 5 - Results of erosion, sediment deposition and sediment yield estimated by the WaTEM-SEDEM model for the different scenarios.

\begin{tabular}{|c|c|c|c|c|}
\hline \multicolumn{2}{|r|}{$\mathbf{R}_{\text {Low }} *$} & \multicolumn{3}{|c|}{ t. $\mathrm{km}^{-2}$ year $^{-1}$} \\
\hline Model & Conservation measures & Erosion & Deposition & Sediment Yield \\
\hline $\mathrm{BAU}$ & $\mathrm{C}_{\text {high }}$ & 135.1 & 65.2 & 69.9 \\
\hline Scenario I & $\mathrm{C}_{\text {low }}$ & $134.3(-0.5 \%)$ & $65.2(0 \%)$ & $69.2(-1 \%)$ \\
\hline Scenario II & $\mathrm{C}_{\text {low }}+\mathrm{CL}+\mathrm{T}$ & $29.6(-356.4 \%)$ & $15.7(-315.2 \%)$ & $13.9(-402.8)$ \\
\hline Scenario III & $\mathrm{C}_{\text {low }}+\mathrm{CL}+\mathrm{T}+\mathrm{APP}$ & $28.3(-377.3 \%)$ & $17.4(-274.7 \%)$ & $10.9(-541.2 \%)$ \\
\hline Scenario IV & $\mathrm{C}_{\text {low }}+\mathrm{APP}$ & $126.5(-6.7 \%)$ & $75.8(13.78 \%)$ & $50.7(-37.8 \%)$ \\
\hline \multicolumn{2}{|r|}{$\mathbf{R}_{\text {High }} * *$} & \multicolumn{3}{|c|}{ t. $\mathrm{km}^{-2}$ year $^{-1}$} \\
\hline Model & Conservation measures & Erosion & Deposition & Sediment Yield \\
\hline BAU & $\mathrm{C}_{\text {high }}$ & 204.6 & 98.8 & 105.8 \\
\hline Scenario I & $\mathrm{C}_{\text {low }}$ & $203.4(-0.6 \%)$ & $98.7(-0.10 \%)$ & $104.7(-1.05 \%)$ \\
\hline Scenario II & $\mathrm{C}_{\text {low }}+\mathrm{CL}+\mathrm{T}$ & $44.7(-358 \%)$ & $23.7(-316.8 \%)$ & $21.0(-403 \%)$ \\
\hline Scenario III & $\mathrm{C}_{\text {low }}+\mathrm{CL}+\mathrm{T}+\mathrm{APP}$ & $42.8(-378 \%)$ & $26.4(-274.2 \%)$ & $16.5(-541 \%)$ \\
\hline Scenario IV & $\mathrm{C}_{\text {low }}+\mathrm{APP}$ & $191.5(-6.8 \%)$ & $114.8(13.9 \%)$ & $76.7(-37.9 \%)$ \\
\hline \multicolumn{5}{|c|}{ *data set from 2013, representative of a dry year with cumulative rainfall lower than the } \\
\hline$* *$ data set & 2014, representative & a wet year with & h cumulative 1 & all abov \\
\hline
\end{tabular}




\section{Figure Captions}

Figure 1 - Location of the Conceição river catchment in Brazil.

Figure 2 - Monthly precipitation and rainfall erosivity in the Conceicao River catchment for the monitoring period (2011-2015).

Figure 3 - Monthly averages (2011-2015) of sediment yield (SY), river water discharge (Q), rainfall (R) for the Conceição River catchment.

Figure 4 - Performance the WaTEM/SEDEM model in predicting sediment yield (SY) for Conceição River.

Figure 5 - Results of erosion, sediment deposition and sediment yield estimated by the WaTEM-SEDEM model for the different scenarios simulated including those with high and low rainfall.

Figure 6 - Spatial pattern of soil erosion within the Conceição River catchment, according to thescenarios simulated with the WATEM-SEDEM model: A): Business-as-usual (BAU) scenario: $\mathrm{C}_{\text {high }}$; B) Scenario I: $\mathrm{C}_{\text {low }}$; C) Scenario II: $\mathrm{C}_{\text {low }}+\mathrm{CL}+\mathrm{T}$; D) Scenario III: $\mathrm{C}_{\text {low }}+\mathrm{CL}$ $+\mathrm{T}+$ APP; E) Scenario IV: $\mathrm{C}_{\text {low }}+$ APP. Where: CL: Crop Leveling; T: Terracing; APP: Areas of permanent forest preservation. 


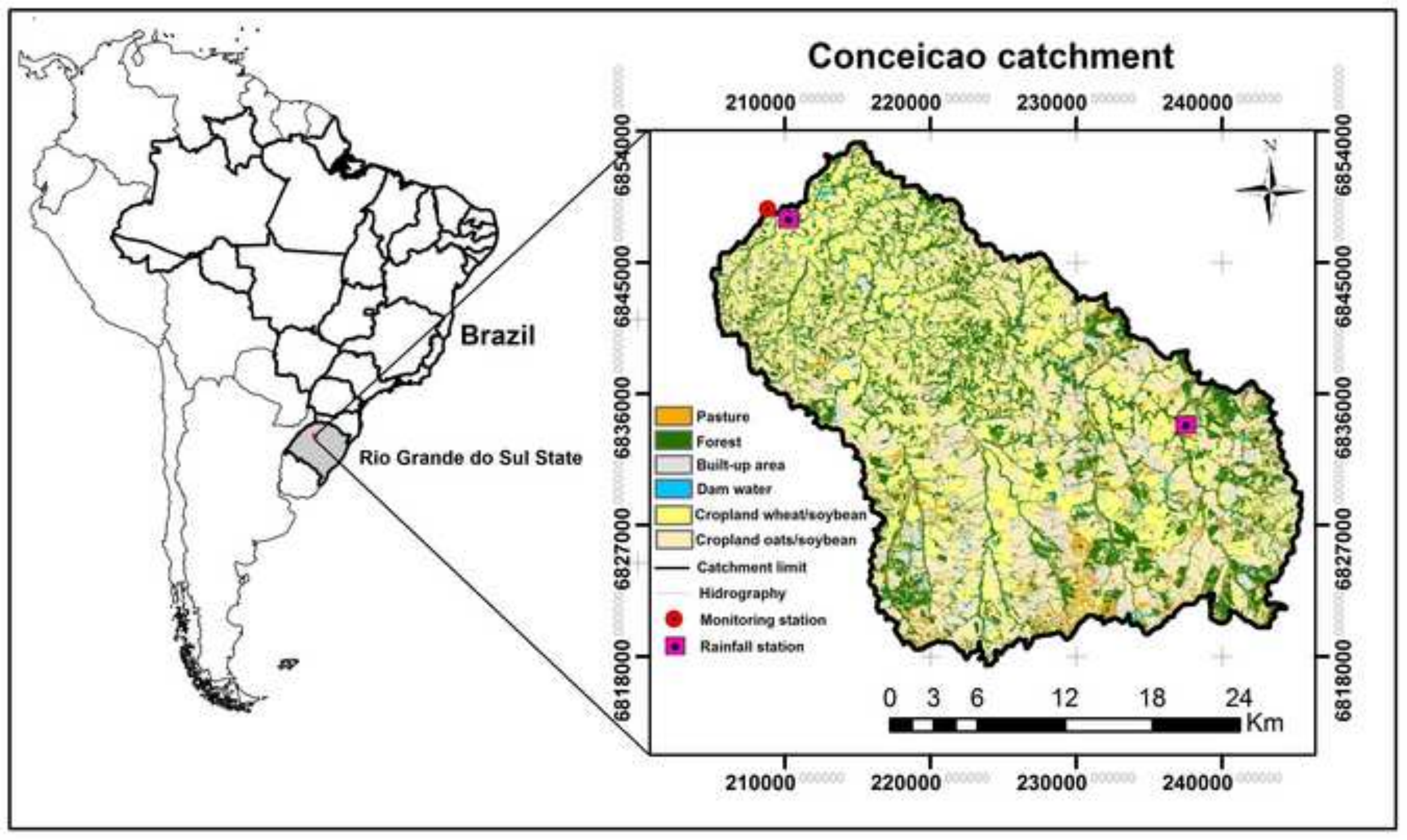


Figure 2
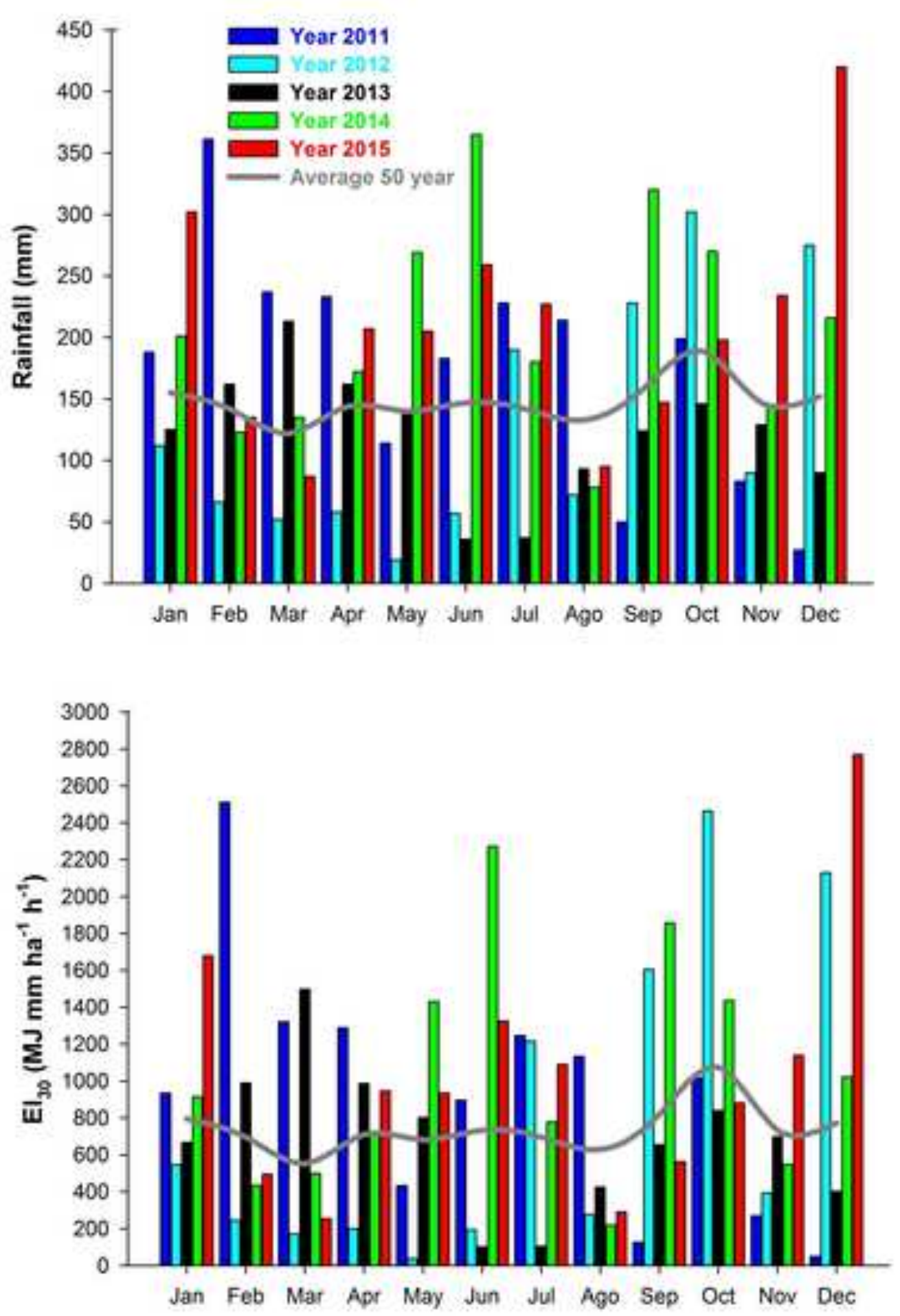


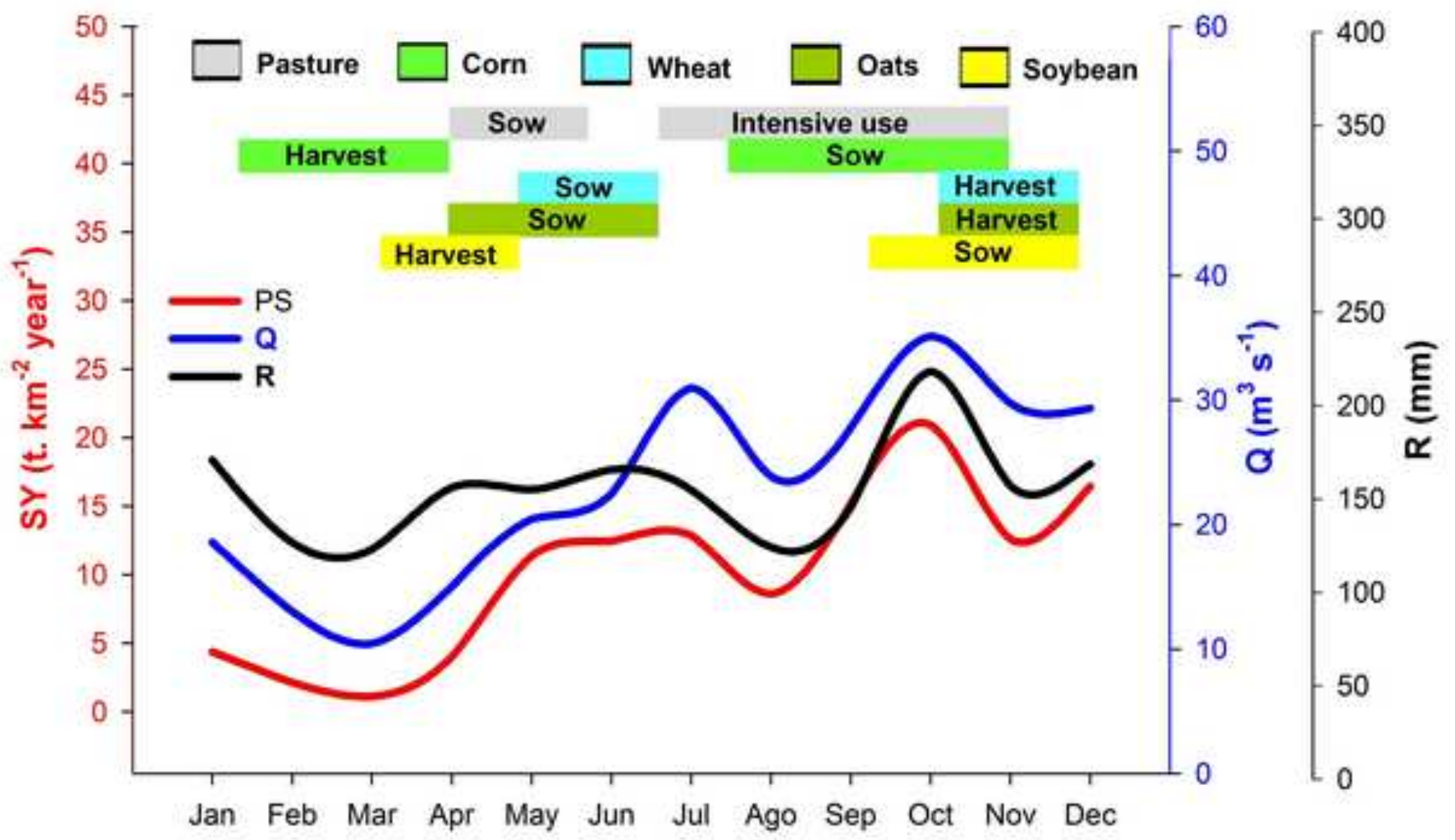




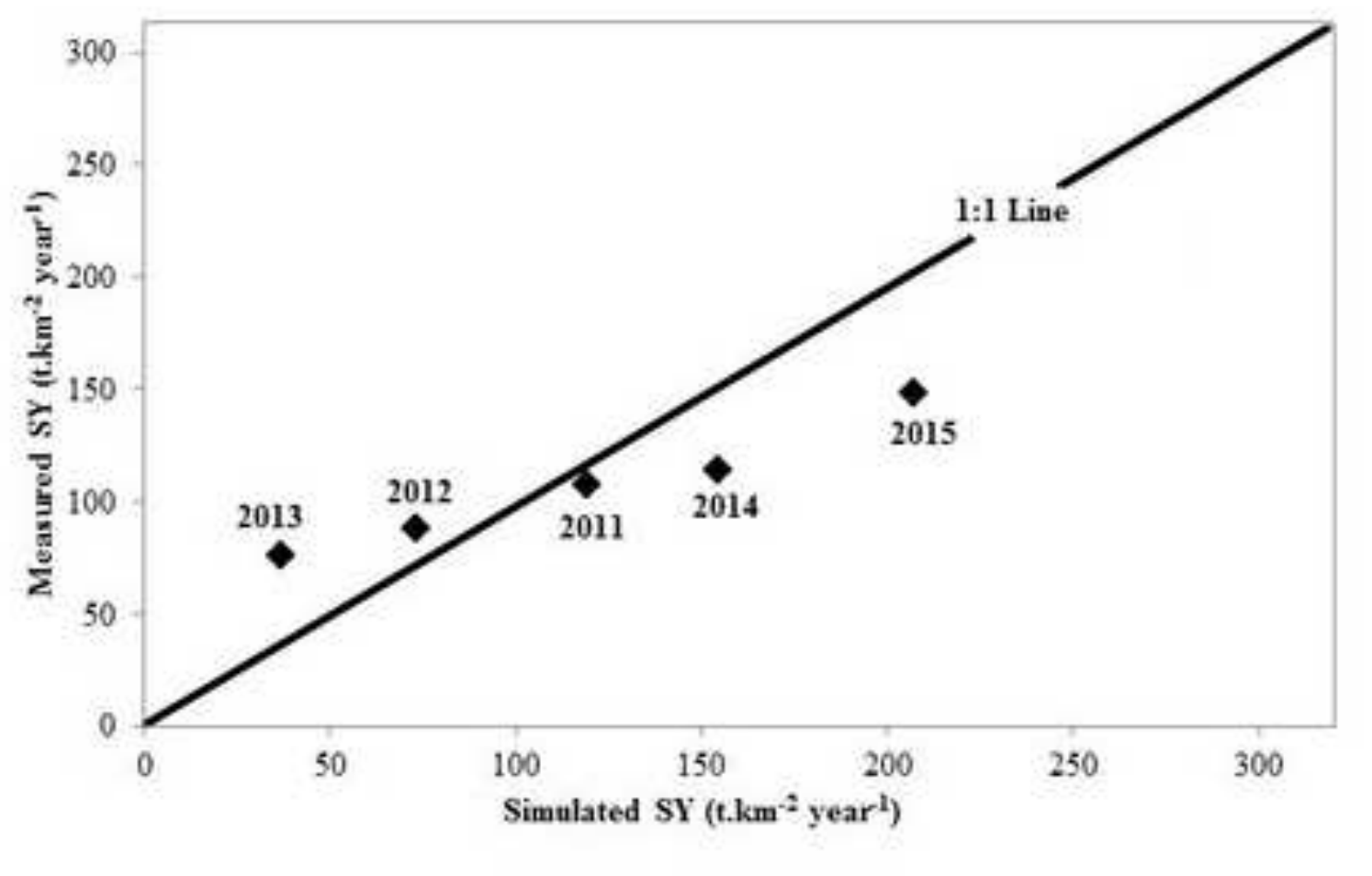

(1)

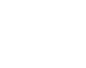




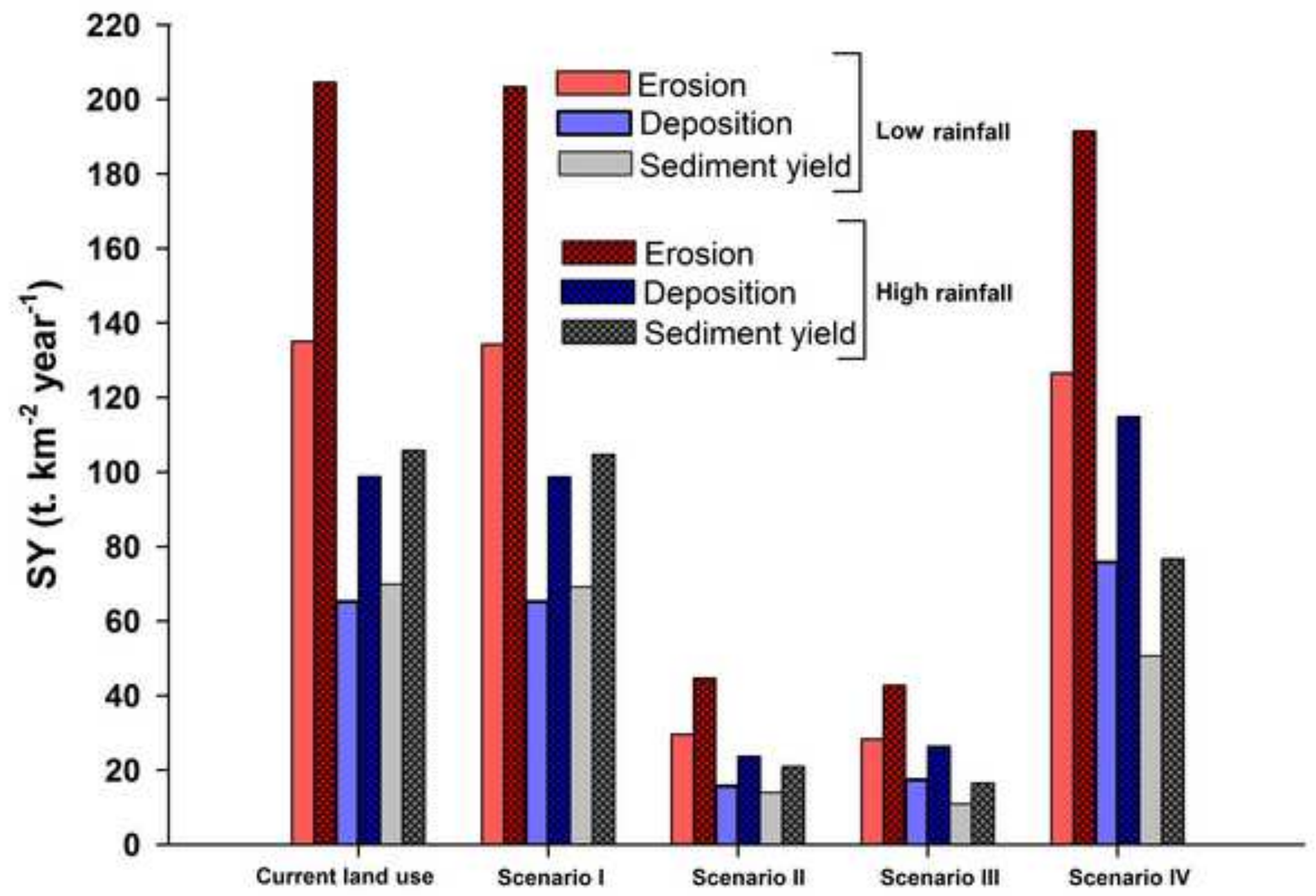




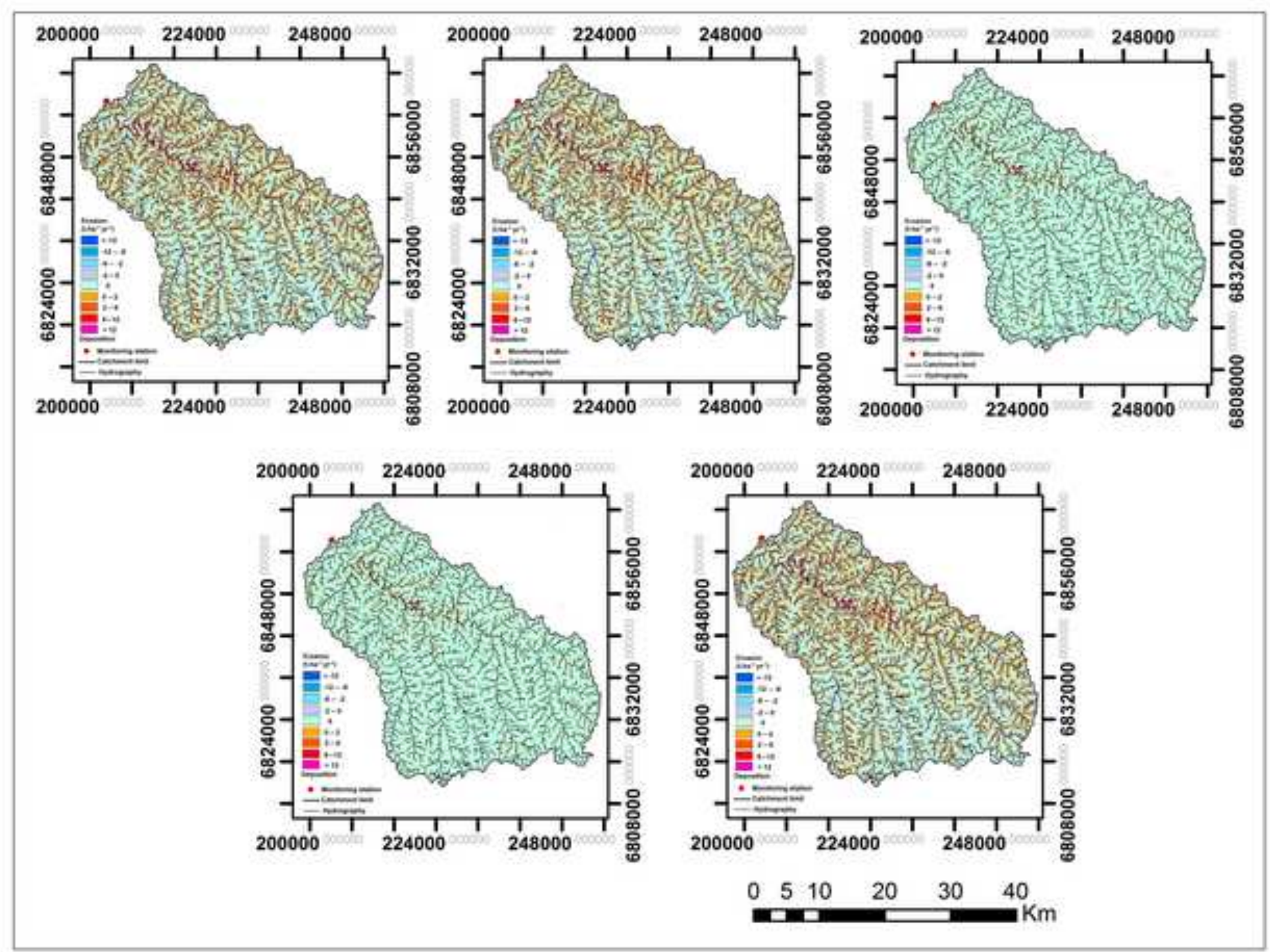

